\title{
Communicative Leadership in Constructing Innovative Learning Organization
}

\author{
LUCY PUJASARI SUPRATMAN \\ Faculty of Communication and Business, Communication Department, \\ Universitas Telkom, Bandung, West Java, Indonesia \\ email: doktorlucysupratman@gmail.com
}

\begin{abstract}
The lecturers have the duties to transfer science and technology and conduct research as well as undertake community service (three pillars of higher education). Telkom University which turned into four years has been working hard to encourage all lecturers in achieving those three pillars. It has given the evident as best classified listings college of Higher Education in Indonesia. The Faculty of Communication is the youngest faculty in Telkom University. This study used qualitative method with descriptive case study. The result is that innovative leadership of the Head of Department is needed to encourage lecturers to achieve comprehensive targets of three pillars of higher education. Head of Department uses Whatsapp Group, creates Gmail Group, posts the achievement photos on social media, has personal discussion of specific issues, and praises the best works of fellow lecturers. These communication forms communicative leadership in motivating lecturers to increase their three pillars on higher education.
\end{abstract}

Keywords: learning organization, leadership, three pillars of higher education

\section{Introduction}

Lecturer job description is stipulated in Law of the Republic of Indonesia No.12 of 2012 on Higher Education which provides that the task of Higher Education is to serve the academic community as a science transformer. The job description is called Tridharma Perguruan Tinggi (The Three Pillars of Higher Education) which should be carried out by all lecturers. On the basis of these pillars, lecturers as the educators have to disseminate the appropriate realm of developed science, continue their simultaneous research, and serve their ideas on the community service. They are also the transformers of science to increase human resources competently.

Under Law No.12 of 2012, lecturers are professional educators and scientists with the main task of transforming, developing, and disseminating through the Science and Technology Education, Research, and Community Service. For these purposes, all lecturers should creating conducive teaching and learning activities atmosphere in the classroom in order to develop students' broaden ideas. In the meantime, the research activities are carried out to deepen theoretical knowledge acquired during the investigation for the benefit of scientific development and the society. The last pillar is community service to help the community solve their problems based on appropriate knowledge in accordance with lecturers' field. Three pillars of Higher Education is the main pillar of lecturers' duty as the intellectuals' builders to advance people knowledge.

However, the statistic data shows that the research competence of Indonesian lecturers is still low. The three pillars realizations are not as much as other developed countries have. One of the rank indicator aspects is the minimum percentage of research grants. Comparing with other countries, the percentage of three pillars on Higher Education produced by Indonesia lecturers is still far above the average. This is the following universities rank of the best three pillar production in the world:

Received: October 28, 2016, Revision: March 30, 2017, Accepted: May 19, 2017

Print ISSN: 0215-8175; Online ISSN: 2303-2499. DOI: http://dx.doi.org/10.29313/mimbar.v33i2.2694.378-388

Accredited B based on the decree No.040/P/2014, valid on February, 18, 2014 until February, 18, 2019. Indexed by DOAJ, Sinta, IPI 


\begin{tabular}{|c|c|c|c|c|c|c|c|}
\hline 2015 & 2014 & Institution & Country & $\begin{array}{l}\text { Academic } \\
\text { reputation }\end{array}$ & $\begin{array}{l}\text { Employer } \\
\text { reputation }\end{array}$ & Citations & $\begin{array}{l}\text { Research } \\
\text { impact }\end{array}$ \\
\hline 1 & 1 & $\begin{array}{l}\text { Stanford } \\
\text { University }\end{array}$ & $\begin{array}{l}\text { United } \\
\text { States }\end{array}$ & 93.10 & 94.9 & 96.30 & 97.4 \\
\hline 2 & 4 & $\begin{array}{l}\text { Harvard } \\
\text { University }\end{array}$ & $\begin{array}{l}\text { United } \\
\text { States }\end{array}$ & 91.80 & 100 & 93.60 & 100 \\
\hline 3 & 3 & $\begin{array}{l}\text { University of } \\
\text { California, } \\
\text { Berkeley (UCB) }\end{array}$ & $\begin{array}{l}\text { United } \\
\text { States }\end{array}$ & 90.7 & 90.2 & 97.4 & 100 \\
\hline 4 & 5 & $\begin{array}{l}\text { Georgia } \\
\text { Institute of } \\
\text { Technology } \\
\text { (Georgia Tech) }\end{array}$ & $\begin{array}{l}\text { United } \\
\text { States }\end{array}$ & 100 & 73 & 88.5 & 91.7 \\
\hline $5=$ & 10 & $\begin{array}{l}\text { Imperial } \\
\text { College } \\
\text { London }\end{array}$ & $\begin{array}{l}\text { United } \\
\text { Kingdom }\end{array}$ & 96.30 & 89.60 & 91.60 & 81.5 \\
\hline $5=$ & 6 & $\begin{array}{l}\text { University of } \\
\text { Cambridge }\end{array}$ & $\begin{array}{l}\text { United } \\
\text { Kingdom }\end{array}$ & 88.80 & 97.80 & 93 & 94.60 \\
\hline
\end{tabular}

Figure 1. World Rank Universities Source: QS Ranking 2015, Higher Education Network.

Based on the above description, the lecturers will contribute ideas and creativity to the development of the nation through three pillars of Higher Education. The lecturer role as a scientist cannot be separated from the mission of the university to devote the knowledge. The existence of university's mission has a big role in expanding the three pillars. As it is written in the Explanation of Government Regulation of Republic Indonesia Number 4 Year 2014 regarding management and organization of higher education, "Misi Utama Pendidikan Tinggi adalah mencari, menemukan, menyebarluaskan, dan menjunjung tinggi kebenaran...sehingga Tridharma Perguruan Tinggi yaitu pendidikan, penelitian dan pengabdian kepada masyarakat dapat dilaksanakan berdasarkan kebebasan akademik dan otonomi keilmuan (The main mission of higher education is to explore, to find, to spread, and to uphold the truth... in order for the Three Pillars of Academic, Education, Research and Civil Service to be done based on academic freedom and scientific autonomy).

Telkom University which just turned into four years has been working hard to encourage all lecturers in achieving the three pillars of higher education. This university has given the evidence on the acquisition of number 34 as the best-classified listings college of Higher Education in 2017 (http:// www.4icu.org/id/).

Telkom University has increased its rank for International publications indexed by Scopus from 33 to 16 with a total of 657 publications. The nation's 16th rank put Telkom University on the First Rank of national private university in Bandung.
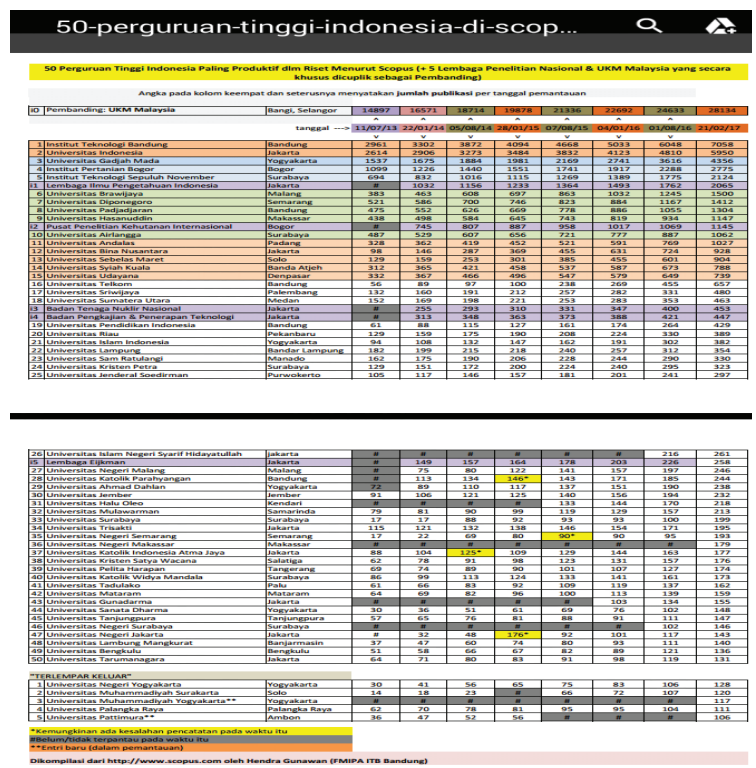

Figure 2. Top 50 Universities with Best Scopus Publication

Source: www.kopertis12

Telkom University has seven faculties. There are Faculty of Electrical Engineering, Faculty of Industrial Engineering, Faculty of Computing, Faculty of Economics and Business, Faculty of Communication and Business, Faculty of Industries Creative, and Faculty of Applied Science. The youngest faculty of Telkom University is Faculty of Communication and Business. Although it is still young, Faculty of Communication and Business has a big number of students. The total number of the departments is divided into three departments of Communication, Business Administration, and Public Relation. Communication Department has the highest number of student body and lecturers. Nevertheless, behind that large number of students, the three pillar production of Communication Department lecturers are considered adequate. These achievements are attained because the head of communication department keeps applying the vision of faculty of communication and business. The vision is "to be the best international rank faculty in communication business field based on information technology". Toward this great vision, communication department has developed good education standard and international reputation in research and publication. It has also implicated to global corporation in international joint researches, international conferences, and international competitions held by communication department.

The importance of learning organization 
will actively work to optimize retaining knowledge in a university. Learning organizations use the active process of knowledge management to design organizational processes and systems that concretely facilitate knowledge creation, transfer, and retention. Organizational learning can be conceived as having three sub-processes: creating, retaining, and transferring knowledge. When organizations learn from experience, new knowledge is created in the organization. The knowledge can be then retained so that it exhibits some persistence over time (Imran, 2016). Knowledge can also be transferred within and between units. Through knowledge transfer, one unit is affected by the experience of another or learns vicariously from the experience of other units (Argote, 2011).

Learning organization processes will be more efficient by incorporating information communication technology into communication process among lecturers. The usage of communication technology devices have been a collaboration tool for transferring, gaining, and sharing academic information. The usage of these communication technology devices can fasten the information, announcement, and everything by saving the time and distance. Communication technology promotes learning organization since it is employed for improving work, sharing knowledge, promoting selflearning, and self-improvement for members of the organization (Koonsri, 2005). Digital information technology (like social media usage or electronic mail) is an important tool for learning organization. In other words, the organization relies massively on modern technology which is most likely to be accurate, easily accessible, and convenient for sharing knowledge. Information technology helps organization and its members to respond to change and increases working effectiveness which eventually leads to organizational development (Thianthai, 2007). Kim (2008) found that the use of information from a communication technology generally had a positive effect on performance, especially for members who did not have alternative sources of information.

Head of Communication Department uses many information technology facilities to establish interactive communication with the lecturers. The use of this technological information helps her facilitate instant messaging. Communication department has the academic freedom to develop and share communication knowledge globally. The Head of the Communication Department supports every effort of communication department lecturers to improve their performances through teaching, research, and community service activities. These form of academic freedom are applied to improve the quality of teaching materials, lecturer competence, digitalized learning media, support the internal and external research by providing academic freedom related to lecturer research expertise, and improve the quality of community service by involving lecturers, students, research directorates and community service. The efforts done by communication department are in accordance with Telkom University policy on the academic atmosphere (stated in the Rector Decision of Telkom University Number KR.078 / AKD27 / WR1 / 2015 About the Academic Rules of Telkom University). Academic freedom in Telkom University is a principle that encourages the process of research, learning method, and scientific publications. Telkom University encourages the creation of academic life in a conducive atmosphere intellectual to implement academic freedom which is beneficial to the academic society development and welfare. The head department often reminds all lecturers about this academic platform on their duties as professional lecturers.

Head of Department who act as the leader in a learning organization (Communication Department, specifically) has a big role to lead the department in reaching the academic target. Leaders in every organization aspect are put in a significant part to guide its members to achieve the targets. In this case, leadership styles and approaches serve as crucial factors in promoting successful learning organization. They have continuously promoted the vision and mission of the organization to reach conducive learning environment. Gilley and Maycunich (2000) said that leadership found in learning organization are likely to be transactional leadership and transformational. Leadership is a key point of success in an organization to manage the organizational learning. Innovative leadership cannot be successful without the support from all organization members. The leaders need to provide clear understanding about the vision and mission concepts of an organizational value. This type of leadership will lead to open communication for the innovative learning organization. Srimuang (2005) stated that in order to advance the learning 
organization, he/she must have the ability to become a leader of change. Leaders are also greatly responsible of indicating strategic direction and supervising staff's performance, thus, giving a great impact on organizational learning culture. They need to be able to promote transformation by making employees understand, admire, and follow the organizational learning culture (Yavirach, 2007).

Therefore, the research question in this study is, "How does the strategic role of Head of Communication Department to motivate the lecturers to be eagerly do The Three Pillars of Higher Education?"

\section{Research Methodology}

This study used qualitative method with the approach of descriptive case study. Qualitative methods are used to find the strategic roles on managing the communication process of information about the leadership style. The writer used purposive sampling by obtaining data from the interview with Head of Communication Department. Collecting the data has been done for one year through observation participation (20162017). The observation run in the phases of how the head of department selected lecturers to become the accredited member based on their abilities, how communication pattern is formed naturally by the innovative leadership in creating Whatsapp group of accreditation, how she motivates all lecturers to be involved as one team to reach the three pillar targets. After the observation, the writer interviewed her informally. Then, the interview transcript statement was modified into a model of innovative leadership which applied by her in communication department.

\section{Communicative Leadership}

A communicative leadership of the Head Department (chairman) is needed to embrace fellow lecturers in order to build solidarity. This kind of leadership style should be applied to achieve comprehensive targets of three pillars academic. Building a university reputation of the best pillars academic is started from the study program. Once an innovative leader leads, the lecturers' performance of study programs will arise in maximum way to increase the three pillars targeting. The three pillars at Communication Department are formed by an innovative leadership figure, which has been done by a chairman of Communication Department. She leads her department with various kinds of innovative leadership. All her leadership is strongly related to the innovative communications. According to Supratman (2011), the activity of human daily basis will never escape from the communication. Humans integrate with each other in domestic life, work, society, milieu, and wherever he/she was located. Communications eventually become an obligatory tool for humans to convey all his/ her ideas and deliver meaning of a context of communication organization. Humans act as members of the organization who share meaningful information. This type of organizational communication is closely linked to the communication leadership style. The Head of Communication Department uses this communication style to gain the understanding of shared-information transactional. The communication medium is the bridges to organizational effectiveness. As Kreps (1986) said, "Information is the mediating variable that connects communication to organization. Communication is a message-gatheringsending and interpreting process that enables people to understand information. And information is used to constrain and coordinate the activities of individuals to establish organization."

The fulfillment of sufficient information (as the process of distribution-collectiondelivery-meaning messages) is an indication for the organization's members to determine the level of understanding of their performance in the organizational system. According to Pace and Faules (2002), an understanding of the information adequacy gives the instructions to members about the organizational aspects, which is one part of the organization's communication climate. Her innovative leadership can create good communication climate to share lecturers' insights. The medium she has been used such as;

These forms of communication media will be the symbolic way of innovative leadership. Yuningsih and Mulyana (2017) said that "interpersonal communication skills include the skills of conducting transactional approaches to build relationships; skills to position themselves in relevant conditions and contexts; skills of self-change and others in accordance with performance demands, and human relations skills to build a conducive atmosphere and working climate." Lecturers and the Head of Department understand the 
Table 1

The Medium of Innovative Leadership Communication

\begin{tabular}{|c|c|}
\hline Innovative Leadership Communication & Media Message Channel \\
\hline \multirow[t]{2}{*}{ Creating a Whatsapp Group called 'Info Ikom'. } & 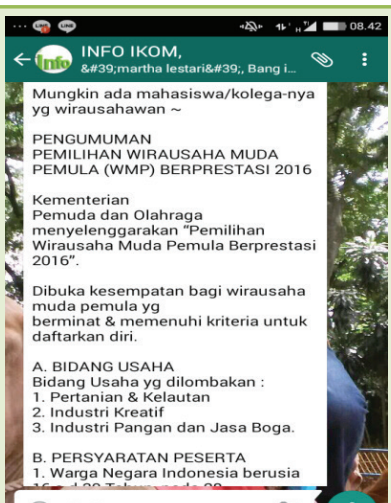 \\
\hline & (:) Kerik pesan 100 \\
\hline \multirow{3}{*}{ Create Gmail to transfer and share the documents easily. } & 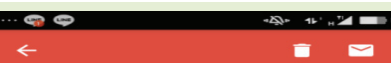 \\
\hline & $\begin{array}{l}\text { [Group IImuan Komunikasi } \\
\text { Teelkom University] Fwd: Memo } \\
\text { Online: : Forward Keseragaman } \\
\text { Sertifikat Pengabdian } \\
\text { Masyarakat dan Ketentuan } \\
\text { Lembar Pengesahan }\end{array}$ \\
\hline & 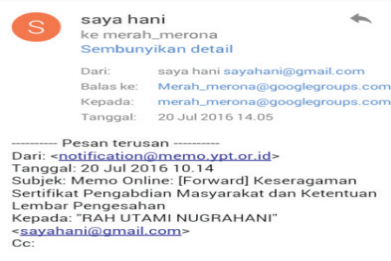 \\
\hline
\end{tabular}

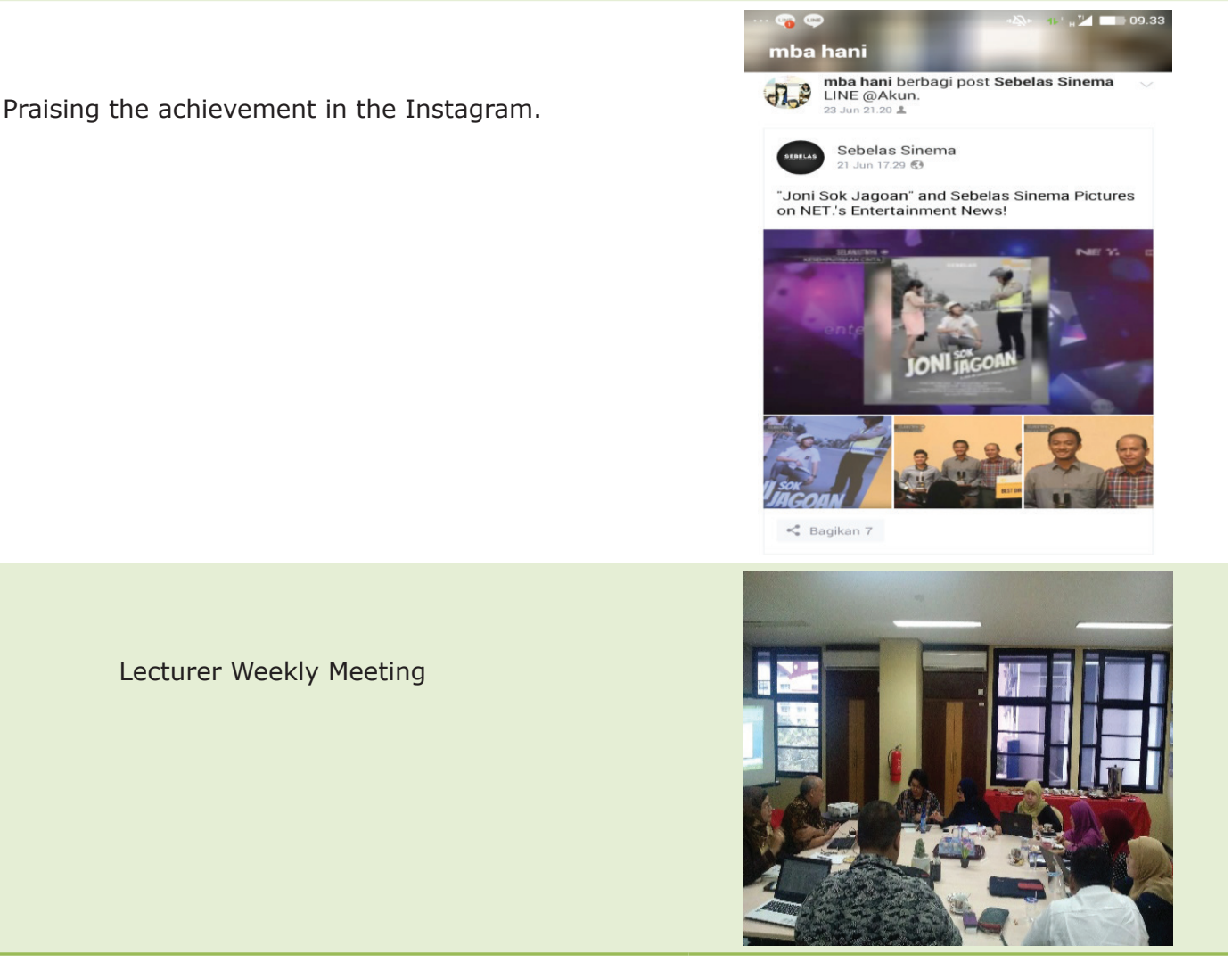

Source: Research Result 
information flow one another. Eventually, these penetrating media have boosted the motivation of the lecturers to increase their three pillars obligation. The lecturers processed and digested data from the Head of Department in their mind. Then, they can freely ask or give any feedback through several media. It is like an organizational communication on cyber world (Whatsapp, Instagram, Gmail, etc). They form a message, respond to messages exchanged, and produce a similarity of meaningful framework into an innovative leadership. Goldhaber says (1993), "Organizational communication is the process of creating and exchanging messages within a network of interdependent relationship to cope with environmental uncertainty". In other words, this kind of leadership creates and exchanges the messages into one web which is bond by the internet network.

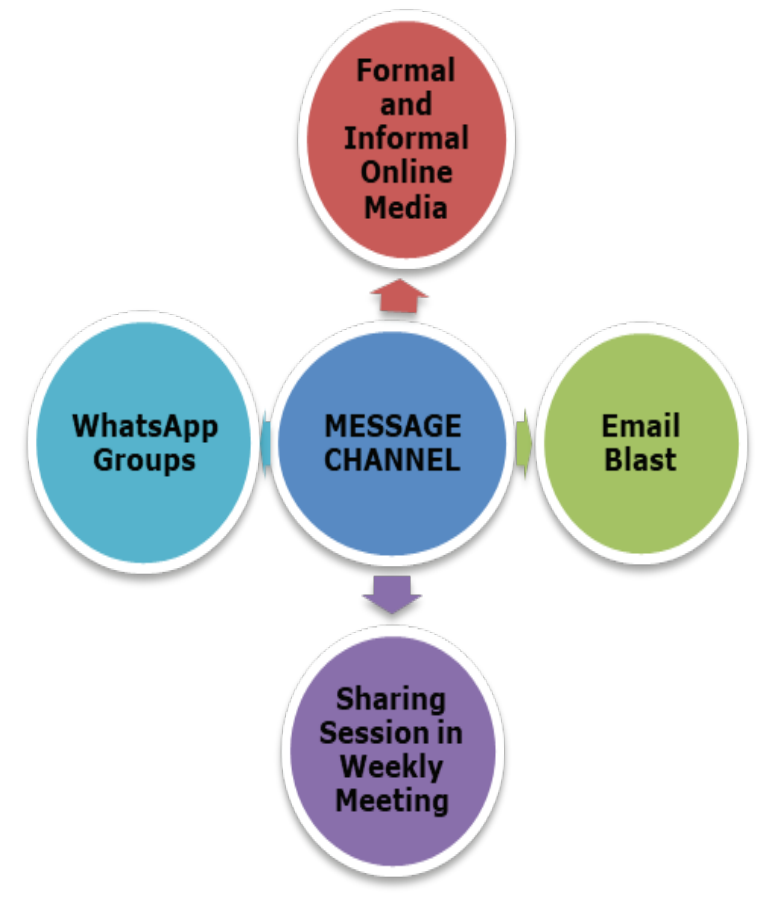

Figure 3. Media Message Channel

Source: Research Result

These communication media channel are transferred with friendly, modesty, and well organized. The message content on four communication media channels above use persuade and informative statement to make the lecturers become more productive in realizing the three pillars of higher education as their academic goals. The head of communication department has become a successful leader who utilized the leadership art in communicating innovative learning organization to the lecturers. Communicative leadership using four various media channel is proved effective to reach the target of Telkom University mission.

There is a study conducted by Pennsylvania State University in 1992 that documented the importance of communication skills for organizational success in Tubbs and Moss (2005) book. The result of the research determined the success of leadership in a learning organization:

Innovative leadership is not only carried out in the internet world. As the Head of the Department, she also does this in reality life. She opens up to any criticism and contribution of ideas at the discussion session in formal or informal situation. The goal of doing an open talk is to achieve a stable organization. Organizations can be defined as individual settings to achieve certain goals deliberately. Every organization should have a goal to reflect the target which is made for short term and long term. She realized that it is impossible to have only one man show to achieve the three pillars goals. It needs the organization crews which consist of a cooperative lecturer's collection to have similar common goals.Sumual (2015) on Journal Mimbar stated that "Kebutuhan akan kompetensi pemimpin menjadi sangat urgen bagi sebuah perguruan tinggi untuk menjawab kebutuhan internal organisasi tetapi juga untuk mengadaptasikan diri dengan tuntutan eksternal" (a requirement for a competent leader is urgent to fulfill the internal organization needs and adapt with external demands)

\section{Innovative Learning Organization}

The three pillars goals can be obtained by all lecturers because the head can deliver clear communication. This innovative leadership with good communication skill has motiv a ted the lecturers to run the goals successfully. It will also minimize the misunderstanding about the job desk and information source to be shared by the Head Department. Misunderstanding will give a big impact for the organizational success. Under the innovative leadership communication skill, she has brought her department as the most productive department in Telkom University in achieving the three pillars. It can be seen from the above chart, there are 114 researches, 116 scientific publications, 20 books, 7 Internatio nal Corporations, 15 copyrights, and 30 civil services in 2015-2017. 


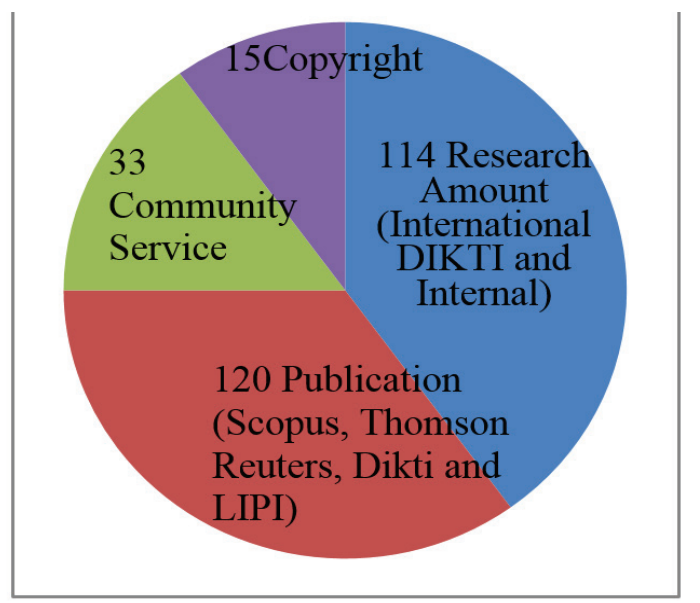

Figure 3. Lecturer Achievement 2015-2017

Having one of the international achievements attained by communication department, Telkom University as an international corporation will expand its coverage to the South East Asia next year (2018). Below are the international corporation lists from the period of 20152017:

Table 2

Rank of Organizational Success

\begin{tabular}{cc}
\hline Rank of Organizational Success & Percentage \\
\hline $\begin{array}{c}\text { Oral and written } \\
\text { communication skills } \\
\text { Leadership skills }\end{array}$ & $(85.3 \%)$ \\
Analytical ability & $(79.7 \%)$ \\
Ability to work in a team & $(71.4 \%)$ \\
The ability to handle rapid & $(65.9 \%)$ \\
change & Sense of social, professional \\
and ethical responsibility & $(64.3 \%)$ \\
Financial management & $(46.7 \%)$ \\
\hline
\end{tabular}

Source: Tubbs and Moss (2005)

Table 3 International Collaboration

\begin{tabular}{|c|c|}
\hline Universities & Goals \\
\hline $\begin{array}{l}\text { Universiti } \\
\text { Utara } \\
\text { Malaysia }\end{array}$ & $\begin{array}{l}\text { Research Collaboration } \\
\text { Agreement. The joint research } \\
\text { program between two } \\
\text { universities and collaborate } \\
\text { publishing in high impact } \\
\text { international journal }\end{array}$ \\
\hline $\begin{array}{l}\text { Universiti } \\
\text { Utara } \\
\text { Malaysia }\end{array}$ & $\begin{array}{l}\text { Student Exchange. The } \\
\text { programme aims to enhance } \\
\text { educational opportunities } \\
\text { and to foster advancement } \\
\text { for the students in cultural } \\
\text { understanding for UUM and Tel-U } \\
\text { Students }\end{array}$ \\
\hline
\end{tabular}

\begin{tabular}{|c|c|}
\hline $\begin{array}{l}\text { Wageningen } \\
\text { University }\end{array}$ & $\begin{array}{l}\text { Research Collaboration } \\
\text { Agreement. This research has } \\
\text { the ambition to create a social } \\
\text { dialogue and increase awareness } \\
\text { on food safety issues. The } \\
\text { result is video movie filmed } \\
\text { data for the food safety policies } \\
\text { and recommendations from } \\
\text { the government (NA-DFC) } \\
\text { as perceived by consumers, } \\
\text { farmers, media, suppliers, and } \\
\text { industries in Indonesia. }\end{array}$ \\
\hline $\begin{array}{l}\text { Multimedia } \\
\text { University } \\
\text { Malaysia }\end{array}$ & $\begin{array}{l}\text { Research Collaboration } \\
\text { Agreement. The research } \\
\text { collaboration provides university } \\
\text { level education, research, } \\
\text { and consultancy to enhance } \\
\text { and strengthen educational } \\
\text { excellence. }\end{array}$ \\
\hline \multirow[t]{2}{*}{$\begin{array}{l}\text { Universiti } \\
\text { Sains } \\
\text { Malaysia }\end{array}$} & $\begin{array}{l}\text { Doctoral Study Program for } \\
\text { Telkom University lecturers. } \\
\text { The collaboration endeavor the } \\
\text { cooperation among parties to } \\
\text { enhance doctoral programs } \\
\text { degree }\end{array}$ \\
\hline & $\begin{array}{l}\text { Joint Research and Publication } \\
\text { Activities. The research } \\
\text { collaboration provides university } \\
\text { level education, research, } \\
\text { and consultancy to enhance } \\
\text { and strengthen educational } \\
\text { excellence. }\end{array}$ \\
\hline $\begin{array}{l}\text { Universiti } \\
\text { Sains } \\
\text { Malaysia }\end{array}$ & $\begin{array}{l}\text { Student and Lecturers Exchange } \\
\text { Programs. The programme } \\
\text { aims to enhance educational } \\
\text { opportunities and to foster } \\
\text { advancement for the students in } \\
\text { cultural understanding for Telkom } \\
\text { University and Universiti Sains } \\
\text { Malaysia }\end{array}$ \\
\hline
\end{tabular}

Communicative leadership of head department constructed lecturers' attitude to be part of the course element in implementing the Telkom university mission. All lecturers follow the shared mission values, ethics, and organizational culture that are mutually agreed. Her leadership formulated a conducive academic climate and articulate realistic vision for the lecturers' development. She also emphasized the harmony of human relations by reminding the lecturers to be 'guyub' (altogether) always.

This form of leadership stimulates academic members to keep the vision of the university in their mind and apply it in activities. The lecturers' feedbacks are providing goals, roles, and duty to serve the university sincerely. Communication interactivity between head of department and all lecturers are held in various types of meetings: 
Table 4

Weekly Meeting

\begin{tabular}{|c|c|}
\hline $\begin{array}{c}\text { Weekly Meeting } \\
\text { Type }\end{array}$ & Goals \\
\hline Coordination Meeting & $\begin{array}{l}\text { The course which resulted } \\
\text { in the implementation } \\
\text { of uniformity in terms } \\
\text { of material perception, } \\
\text { RPS, teaching materials } \\
\text { (teaching slides and books), } \\
\text { written test, and joint } \\
\text { assessment. }\end{array}$ \\
\hline $\begin{array}{l}\text { Academic Meeting of } \\
\text { faculty level }\end{array}$ & $\begin{array}{l}\text { The result of this meeting } \\
\text { is graduation of students } \\
\text { of grade I, II, III, and IV } \\
\text { (Bachelor). It is also discuss } \\
\text { student academic cases } \\
\text { from special examination to } \\
\text { academic crime case. }\end{array}$ \\
\hline $\begin{array}{l}\text { Lecturer meetings } \\
\text { at the level of study } \\
\text { program and faculty }\end{array}$ & $\begin{array}{l}\text { The results of this meeting } \\
\text { discuss the progress and } \\
\text { development of future } \\
\text { study programs including } \\
\text { discussing together the } \\
\text { problems existed. }\end{array}$ \\
\hline $\begin{array}{l}\text { Coordination Meeting } \\
\text { of Course Capability }\end{array}$ & $\begin{array}{l}\text { The result is the plotting } \\
\text { of teaching schedules by } \\
\text { taking into account the } \\
\text { inputs from all lecturers. } \\
\text { This meeting is also a } \\
\text { meeting place for lecturers } \\
\text { at the same court. }\end{array}$ \\
\hline $\begin{array}{l}\text { Parallel Course } \\
\text { Coordination Meeting }\end{array}$ & $\begin{array}{l}\text { Study groups and seminars, } \\
\text { thesis hearings, and } \\
\text { seminars outside the } \\
\text { institution which provide } \\
\text { strong academic interaction. }\end{array}$ \\
\hline
\end{tabular}

Source: Research Result

It is clearly seen that communication skills play an important role in leadership. The innovative leadership creates an effective communication and mutually understanding among the members. As Supratman (2016) said in the previous research about supervisors' leadership: the role of supervisors can be very successful in transferring teamwork philosophical message by using open communication from supervisors to the staff. It would lead to the trust and effectiveness of organizational communication and also minimizing misunderstanding among all staff members. However, the communicative leadership which has been applied by head of communication department is more opened in academic areas. Each lecturer can greet each other, ask for a help, and share academic information freely without being afraid or worried of being controlled.

The $3 \mathrm{~S}$ (Solid, Speed, Smart) is a great spirit of Telkom University culture. 'Solid' means the realization of one heart, one mind, and one action. The existence of solidarity will deliver true friends and that means to have mutual love, to protect each other, and to defend each other. 'Speed' is a mental attitude to act as a pioneer based on the direction that has been determined in the form of action to build the fastest responding for stakeholders need. 'Smart' is the way to think and act intelligently in the workplace. Smart is manifested through the deep intuition and the deep intuition exercise is done through creativity and innovation that generates breakthroughs.

\section{Table 5 \\ Form of Greeting In a Formal Meeting}

\begin{tabular}{|c|c|}
\hline Greeging & Goals \\
\hline $\begin{array}{l}\text { Head of } \\
\text { Department: } \\
\text { Semangat Pagi! } \\
\text { (Good Morning!) } \\
\text { The Lecturers: } \\
\text { Pagi! Pagi! Pagi! } \\
\text { (Morning! Morning! } \\
\text { Morning!) }\end{array}$ & $\begin{array}{l}\text { This greeting is } \\
\text { used not only in the } \\
\text { morning, but also } \\
\text { after the meeting } \\
\text { in the afternoon or } \\
\text { evening and greet } \\
\text { the same content } \\
\text { of 'Semangat Pagi' } \\
\text { (Morning Spirit). It } \\
\text { has been an opening } \\
\text { tradition greets to } \\
\text { open a meeting or an } \\
\text { activity to restore the } \\
\text { spirit of working. }\end{array}$ \\
\hline $\begin{array}{l}\text { Head of } \\
\text { Department: } \\
\text { Telkom Group? }\end{array}$ & $\begin{array}{l}\text { This 3S (Solid, Speed, } \\
\text { Smart) greeting is } \\
\text { pronounced by the } \\
\text { academic staff to keep } \\
\text { remembering and be } \\
\text { aware of applying the } \\
\text { Telkom Group core } \\
\text { values in advancing } \\
\text { Telkom University } \\
\text { Mission and Vision. }\end{array}$ \\
\hline
\end{tabular}

Source: Research Result

The head had already given the academic liberty to expand the knowledge among colleagues. Such academic liberty philosophy is taken to reach the goal of becoming World Class University. Moreover, the basic pillar to construct innovative learning organization in Telkom University is derived from the 'Telkom Way'. 'Telkom Way' is corporate philosophy to be the best in all aspect (Integrity, Enthusiasm, and Totality). Integrity is the blend of belief toward the core values which embraced mind and its action. The essence of integrity is honesty which manifested from 
the harmonious of people beliefs, thoughts, and deeds. While enthusiasm is the desire to deliver people passion because of having the greatest hope to be the best, and totality is dedicating all the potential and ability to be the best. It is also called the basic belief.

All academic staffs in Telkom University should internalize this basic belief as their core values to comprehend professionalism in three pillars of higher education. Telkom University adopts "The Telkom Way" into a philosophy of PRIME. PRIME stands for Professionalism, Recognition of Achievement, Integrity, Mutual Respect, and Entrepreneurship.

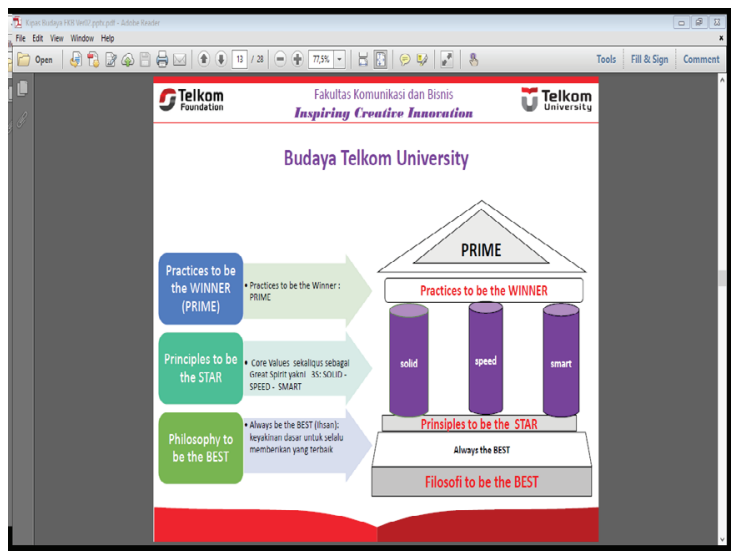

Figure 4. Telkom University Culture Source: Rujukan Budaya Telkom University

Core values of Professionalism, Recognition of Achievement, Integrity, Mutual Respect and Entrepreneurship have led Telkom University to be the best private university in Indonesia. Professionalism is the ability of Telkom University academic community to carry out the role according to the job competence and profession demands. Professionalism is demonstrated by the ability to utilize science, skills and attitudes in completing each job and task with the best quality for the lecturers. Recognition of achievement is an attitude that shows the sincerity of Telkom University academic community to acknowledge and appreciate other people's work. Recognition is shown by giving appreciation in the form of speech, attention, action, or other rewards. Telkom University academic community with its noble initiative keeps inviting all members of Telkom University academic community to perform positively. Integrity reflects on the attitude of the Telkom University academic community to keep maintaining good manner in accordance with prevailing norms and ethics; maintaining good relationships with fellow employees, students, and all stakeholders; honesty, trustworthy, independent, obedient, and truthful. Mutual respect is the commitment of Telkom University academic community to build Telkom University based on the principle of trust, togetherness, cooperation, mutual respect, harmony, and desire to do the good thing for all lecturers. Finally, entrepreneurship is the ability of Telkom University academic community to create useful innovative products/activities to improve the welfare, knowledge and productivity of lecturers, students and Telkom University, and to have the ability to invite and cooperate with prospective students, industry, and society.

Table 6

The Competence of Telkom University Culture (PRIME)

\begin{tabular}{|c|c|}
\hline $\begin{array}{l}\text { Telkom University } \\
\text { Values }\end{array}$ & Competence \\
\hline \multirow[t]{4}{*}{ Professionalism } & $\begin{array}{l}\text { Quality of Product and } \\
\text { Service }\end{array}$ \\
\hline & Perfection in Work \\
\hline & Customer Delight \\
\hline & $\begin{array}{l}\text { Continuous Improvement } \\
\text { Decisiveness }\end{array}$ \\
\hline \multirow{4}{*}{$\begin{array}{l}\text { Recognition of } \\
\text { Achievement }\end{array}$} & Develop the people \\
\hline & $\begin{array}{l}\text { Respect for the individual } \\
\text { Tolerance (open minded) }\end{array}$ \\
\hline & Caring \\
\hline & A will to succeed \\
\hline \multirow[t]{5}{*}{ Integrity } & Commitment \\
\hline & Honesty \\
\hline & Openness \\
\hline & Responsibility \\
\hline & Loyalty \\
\hline \multirow[t]{5}{*}{ Mutual Respect } & Goodness \\
\hline & Trust \\
\hline & Harmony \\
\hline & Cooperation/Team Work \\
\hline & Tolerance \\
\hline \multirow[t]{5}{*}{ Entrepreneurship } & Creativity \\
\hline & Innovation \\
\hline & Decision making \\
\hline & Taking risk \\
\hline & Initiative \\
\hline
\end{tabular}

Source: Rujukan Budaya TelkomUniversity

The socialization of communicative strategy about this core values of Telkom University culture to the academic community (especially the lecturers) are always pronounced in every meeting. The goal is to achieve the vision and mission of Telkom University. The comprehending of core values and Telkom University culture is very significant in a learning 
organization. It is to maintain and advance all academic community's understanding about the code of conduct and their roles as part of Telkom University academic community. Telkom university culture refers to the core values of Telkom Indonesia (Solid, Speed, and Smart). Solid defined as the value of solidity in a workplace. The value of solid refers to the element of spirituality where every people in a team have a strong solidarity to cooperate with peers, top management, or in a teamwork. The value of speed refers to the element of physical strength where people must work fast, responsive, and appropriate. Smart is described as intelligence. This smart value related to the skill workability. Telkom University academic community is expected to have creative thinking and innovative decision making in solving the problems at a workplace.

\section{Conclusions}

The head of communication department has communicative leadership skills to implement innovative organization climate in the academic atmosphere. Her purpose is to transfer the mission of university and communication department association in mobilizing the lecturers to run the education world in accordance with the three academic pillars. In her two periods of leadership, the lecturers of communication have shown the encouraging attitude and qualified performance in running the three pillars (teaching, researching and community serving). The positive implication of professional lecturer's performance under her leadership brings good impact to the publication quantities and human resource qualities. Through these kinds of innovative encouragements, the lecturers will continue to be motivated to carry out their responsibilities as lecturers and will create loyalty to the university. As Robbins (2003) says that a leader must be a charismatic, transactional, and a visionary leader. The head of communication program runs her leadership communication skill based on the mission of communication department. The mission of Communication Department Program are (1) Organize and develop the international standard education in Communication Science, (2) Develop and disseminate international standard research and publication in Communication Science, (3) Produce the superior copyrights in the field of Communication Science for the welfare and development of national civilization. In addition, she also uses new media such as Whatsapp group, Facebook, Gmail, and Igracias Computer Network System to have an instant and communicative interaction. She formed transactional communication to convey ideas and instructions in lecturer meeting with modest expression. She helped all lecturers to solve all academic problems in the study program wisely. Apart from that, her visionary thoughts have provided visionary steps, so that communication department has already gone international. The visionary programs is student exchange international program with Universiti Utara Malaysia and international class program with full English language as intermediate language in teaching and learning method.

The lecturers are required to fulfill the role of the three pillars mission of higher education. They have the tasks of teaching, conducting research as well as community service. Unfortunately, Indonesia is still far away from reaching the highest rank as World Class University. This research is deal with the innovative leadership to boost the spirit of lecturers to achieve their pillars goals as lecturers. The three pillars will be effective when the Head of Department implements the innovative leadership. Through this innovative leadership, the Head of Department will empower the competence of the lecturers in order to carry out the three pillars goals. This communication leadership arrangement has let the Head of Department to focus on the development organization members to improve their capabilities as lecturers.

\section{References}

Argote, Linda. (2011).Organizational Learning Research: Past, Present and Future, International Journal of Management Learning, Vol.42, No.4, pp.439-446.

Gilley, Jerry. W., \& Maycunich, Ann. (2000). "Beyond the Learning Organization: Creating a Culture of Continuous Growth and Development Through State-of-theArt Human Resource Practices",Cambridge: Perseus Books.

Goldhaber, Gerald M. (1993). "Organizational Communication", University of Michigan: Brown and Benchmar.

Government Regulation of Republic Indonesia Number 4 Year 2014. (2014). Regarding Management and Organization of Higher Education, Jakarta.

Imran, A y ub Ilfandy. (2016). Individual Innovati veness as a Mediating Factor between Selected Communciation Factors 
and Career Advancement. Dissertation. Malaysia: International Islamic University Malaysia (IIUM).

Kim, S. H. (2008). An Empirical Assessment of Knowledge Management Systems. Unpublished Doctoral Dissertation, Carnegie Mellon University, Pittsburg.

Koonsri, S. (2005). Organizational Development with Information Technology. (http://www.hrcenter.co.th/columndetail. php?column_id=440\&page $=1$ ) diunduh pada 5 Oktober 2017.

Kreps, G. L. (1986). "Organizational Communication: Theory and Practice." White Plains, New York: Longman.

Law of the Republic of Indonesia No.12of 2012 on Higher Education. (2012).Regarding the Higher Education, Jakarta.

Pace, R. Wayne and Don F Faules. (2002). "Organizational Communication". Englewood Cliffs, New York: Prentice Hall.

QS Ranking. (2015). Higher Education Network.(http://www.4icu.org/id/) diunduh pada 30 Oktober 2017.

Rector Decision of Telkom University Number KR.078. (2015). About the Academic Rules of Telkom University, Bandung.

Rujukan Budaya Telkom University. (2013). Peraturan PD.201.00/2013 Perihal Arsitektur Kepemimpinan dan Budaya Perusahaan Telkom Group dan Peraturan PR.201.01/2013 perihal Budaya Perusahaan Telkom Group, Bandung.

Srimuang, A. (2005). HR and Learning
Organization Development. Knon Magazine. Vol 26, No. 1, pp. 38-42.

Sumual, Tinneke E.M. (2015). Pengaruh Kompetensi Kepemimpinan, Budaya Organisasi terhadap Kinerja Pegawai di Universitas Negeri Manado, Jurnal Mimbar, Vol. 31, No.1. pp 71-80.

Supratman, Lucy Pujasari and M Haidy Zulfikar. (2016). Studi Kasus tentang Model Komunikasi Organisasi Supervisor dalam Membangun Teamwork di Divisi Broadband \& Digital Sales PT Telkomsel Branch Ambon, Indonesia. Jurnal Sosioteknologi, Vol. 15, No.2, pp 213-220.

Supratman, Lucy Pujasari. (2011). Komunikasi Terbuka Pimpinan bagi Efektifitas Kinerja Komunikasi Organisasi. Ragam Komunika, Kementrian Komunikasi dan Informatika Republik Indonesia, Balai Pengkajian dan Pengembangan Komunikasi dan Informatika, Vol. 5, No.1, pp 1-10.

Thianthai, C. (2007). "Management: an Executive Perspective", Third Edition, Bangkok: Mcgraw-Hill.

Tubbs, Stewart L and Sylvia Moss. (2005). "Human Communication". South African Edition: McGraw Hill Higher Education.

Yavirach, N. (2007). "Modern Management". Bangkok: Triple Group Company Limited.

Yuningsih, Ani and Dadan Mulyana. (2017). Communication Pattern and Skill of Leaders in Private University Management. Jurnal Mimbar, Vol. 33 Number.1, pp 166173. 